\title{
STUDENTS' PERCEPTIONS OF E-LEARNING FOR ESL/EFL IN SAUDI UNIVERSITIES AT TIME OF CORONAVIRUS: A LITERATURE REVIEW
}

\author{
Khaled Layali \\ Department of English, Police Academy, Cairo, Egypt \\ E-mail: klayali@alliant.edu \\ Ahmed Al-Shlowiy \\ Department of English Language \& Preparatory Year Institute, Jubail, KSA \\ E-mail: shlowiy_a@jic.edu.sa
}

\begin{abstract}
APA Citation: Layali, K., \& Al-Shlowiy, A. (2020). Students' perceptions of e-learning for ESL/EFL in Saudi universities at time of coronavirus: A literature review. Indonesian EFL Journal, 6(2), 97108. doi: $10.25134 /$ ieflj.v6i2.3378.
\end{abstract}

Abstract: Coronavirus (COVID-19) was declared a world pandemic by the World Health Organization (WHO) on January 30, 2020. As a safety measure to protect people, most governments in the world, including Saudi Arabia, decided to close universities and workplaces. Prompted by this shut down, the researchers aimed to review the students' perceptions of e-learning for ESL/EFL in Saudi universities at this Coronavirus time. As such, this review reported on four primary studies that were found relevant to its focus during the period from January 2020 till April 2020 (Abu-Ayfah, 2020; Ahmad, 2020; Alshehri \& Cumming, 2020; Hakami, 2020). As a historical perspective of the review's focus, it also reported on other four primary studies dating back to 2018 and 2019 (Alshehri, Rutter \& Smith, 2019; Mutambik, 2018; Oyaid \& Alshaya, 2019; Sharma, 2019). The review's objectives were to report: 1) students' perceptions of e-learning for ESL/EFL, 2) benefits of e-learning for ESL/EFL, and 3) drawbacks of e-learning for ESL/EFL in Saudi universities. Moreover, this review was compared to a conference paper from China $(\mathrm{He}, 2020)$ as it presented a strategy to continue college English learning and teaching at Coronavirus time. Results showed students' positive views, many benefits and limited drawbacks of e-learning for ESL/EFL in Saudi universities.

Keywords: e-learning; ESL/EFL; students' perceptions; benefits and drawbacks; Saudi education.

\section{INTRODUCTION}

On December 31, 2019, Chinese health authorities informed the office of the World Health Organization (WHO) in China of cases of pneumonia of unknown cause. These cases were first detected in Wuhan city, Hubei province. By January 3, 2020, 44 patients of pneumonia were reported. These cases were associated with exposure to one seafood market in Wuhan city according to the first Coronavirus situation report (WHO, 2020).

The Chinese health authorities identified a new virus that attacked humans by January 7, 2020. It was called new Coronavirus or novel Covid-19 since the first cases were discovered in December 2019. On January 13, the Ministry of Public Health in Thailand reported the first case of Coronavirus. On January 15 Japan reported its first case of the new virus. On January 20, the Republic of Korea declared its first case of the virus based on the first Coronavirus situation report (WHO, 2020).

On January 30, a World Health Organization (WHO) Emergency Committee on COVID-19 was convened and under the International Health Regulations (IHR 2005) declared the outbreak of Coronavirus to be a public health emergency of international concern, in other words, a world pandemic. Although there is still nor vaccine neither a specific anti-viral treatment for this virus, the WHO believed it was possible to stop or decrease the spread of Coronavirus if countries took stringent measures to detect cases early, isolate these and consolidate social distancing measures, as shown in the eleventh Coronavirus situation report (WHO, 2020). As of April 15, 2020, there were 2,029,974 confirmed cases of Coronavirus; 494,578 have recovered and 129,264 have died worldwide (Worldometer, 2020).

\section{Coronavirus in Saudi Arabia}

On March 2, 2020, the Ministry of Health in Saudi Arabia confirmed the first case of COVID-19. On March 8, authorities announced that all confirmed cases in the country came from Qatif. Therefore, the 
Saudi government imposed a curfew on the Qatif Governorate in the Eastern Region of the country (Arab News, 2020).

On March 8, the Ministry of Education announced the suspension of all educational institutions, including universities, schools, technical and vocational training institutions to combat the spread of the virus (Arab News, 2020).

On March 20, the Saudi government suspended entry to and praying in the two Holy Mosques in Mecca and Medina to limit the spread of the Coronavirus. Daily and Friday congregational prayers were also suspended in all mosques across the country (Saudi Gazette, 2020).

On March 24, a curfew across the country was imposed which restricted movement to between 6 a.m. and 7 p.m. On April 6, a full curfew was announced in Saudi major cities which restricted movement to only essential travels between $6 \mathrm{a} . \mathrm{m}$. and $3 \mathrm{p} . \mathrm{m}$. Moreover, the Ministry of Municipal and Rural Affairs announced the closure of shopping malls, restaurants, coffee shops, and public parks. Only pharmacies and supermarkets were allowed to be open (Alarabiya, 2020). As of April 15, 2020, Saudi Arabia had 5,862 confirmed cases; with 931 recoveries and 79 deaths (Worldometer, 2020).

Focus of the review

Prompted by the suspension of universities and schools in Saudi Arabia, the researchers sought to review students' perceptions of e-learning for ESL/EFL in Saudi universities at Coronavirus time. Elearning can be defined as learning or education delivered electronically (Li, Lau \& Dharmendran, 2009). Moreover, it is defined as enhancing students' learning via any suitable information and communication technologies (Ellis, Ginns \& Piggott, 2009).

The researchers adopted the latter definition in their review and looked for primary studies that utilized any information and communication technologies suitable for students' learning of English. Thus, e-learning could comprise online Learning Management Systems (LMSs) such as WebCT, Blackboard and Moodle; video-conferencing tools such as Skype and Zoom; Mobile applications such as Telegram and WhatsApp; and Social Media sites such as Facebook, Blogs, Wikis and Google Docs. These technologies include both means of communication: synchronous (i.e., chatrooms, Listservs) and asynchronous (i.e., e-mails, discussion boards) for educational purposes.

The researchers focused on students' perceptions rather than the teachers' or administrators' and policy makers' perceptions. Also, they focused on Saudi high educational institutions rather than public schools.

The researchers used both the terms English as a Second Language (ESL) and English as a Foreign Language (EFL) for learning English in Saudi Arabia. Some researchers used the term ESL broadly to mean learning English by non-natives whether in an English-speaking country or not (Nepomuceno, 2011). Others insisted on using the term EFL for learning English by non-natives outside English speaking countries (Kitchakarn, 2012).

The importance of the focus

Students' perceptions are important as the researchers subscribe to the learner-centered education with its many benefits. In student-centered learning, students share responsibility of their learning with their teachers, interact with the teachers, and collaborate as well as communicate with each other (Oinam, 2017).

Moreover, e-learning tools, platforms, and applications draw on the web 2.0 technology. Such a technology through its interactive interface and two-way communication and discussion between students and teachers and among students has the potential to enhance social learning where students support each other and the teachers scaffold students via feedback (Hartshorne \& Ajjan, 2009; Vygotsky, 1978). This interactive feature promotes collaboration among students and autonomy of learning with less dependence on the teachers.

Furthermore, Saudi universities use English as the medium of instruction whereas schools use Arabic as the medium of instruction. In Saudi universities, English is used in scientific majors such as medicine and engineering. Arabic is used in humanities' majors, but students in those majors must complete an EFL course as a requirement for graduation (Alrashidi \& Phan, 2015).

Historical perspective of the review's focus

Favorable students' perceptions of e-learning have been well-documented in literature. Sharma (2019) used 60 Saudi EFL learners in the preparatory year at Jazan University. One of the research questions was: What are Saudi students' attitudes toward using social media to support their EFL learning, 
mainly at Jazan University? One of the hypotheses was: Saudi students at Jazan University have positive attitudes toward using social media to support their EFL learning. A questionnaire (with 5point Likert scale) was used based on and adapted from Aifan (2015). Results showed that students had a positive attitude toward using Social Media (SM) to support their EFL learning. Moreover, results showed that students at Jazan University preferred to use WhatsApp followed by YouTube as their most frequently used SM platform. Finally, the students' concern was to protect their privacy when using such SM platforms.

Alshehri, Rutter and Smith (2019) used two surveys to evaluate the usability of the e-learning system (i.e., Blackboard) in the King Khalid University (KKU) and the students' perceptions of its usability features such as information quality, navigation and learnability of the system. Two hundred fifty undergraduate students at KKU answered the surveys; 181 complete surveys were used. All participants used Blackboard to study their majors in different colleges. Results showed that students perceived the most important usability features of Blackboard were information quality, navigation and learnability respectively. This meant that students rated the information quality as the first usability feature of Blackboard reflecting its importance. Then, students rated navigation (i.e., ease of navigation, clear organized icons, etc.) as the second usability feature of Blackboard. Finally, students thought that learnability (i.e., easy to learn, not complicated, user-friendly, etc.) came as the third usability feature.

Oyaid and Alshaya (2019) reported on Saudi university students' perceptions of using E-books for learning. Twenty-seven students of educational technology course downloaded the E-book app. on their smart phones and tablets and were encouraged to use all features of the app. for one semester. A discussion group was held to delineate the students' views of the application. Results showed that students thought the most important E-book features were interactivity, user-friendly interface and the ability to highlight important parts of the E-book text. Furthermore, students believed that simple, well-organized clear icons and easy to navigate interface were also essential characteristics in the application. However, some students reported some problems in the application, such as not being able to use the copy and paste feature to copy some parts of the text to other applications, and not being used to study from a screen. Finally, students expressed their intentions to use E-books applications in their future studies.

Mutambik (2018) investigated students' and teachers' perceptions of using e-learning for EFL learning in Saudi schools. Group interviews were used (2 groups of 8 students and 2 groups of 4 teachers). Students and teachers were grouped based on their gender and e-learning use. Males and females were interviewed separately for religious and cultural practices in the KSA. Students reported benefits of e-learning for improving their English listening and speaking. This was also supported by the teachers. One reason for this may be because such skills are not well practiced in the face-to-face traditional classes in Saudi schools. Moreover, students mentioned many benefits of e-learning such as independent learning, flexible learning and interactive learning. They stated students can access information on their own outside class with $24 / 7$ flexibility of time and interact with each other and with their teachers if needed. For an outline of the historical perspective's four studies, please refer to Table 1.

Table 1. Outline of the historical perspective's four studies

\begin{tabular}{llll}
\hline $\begin{array}{l}\text { Study/participants/setting } \\
\text { /instrument/platform }\end{array}$ & Research question(s) & $\begin{array}{l}\text { Results } \\
\text { (benefits) }\end{array}$ & $\begin{array}{l}\text { Results } \\
\text { (drawbacks) }\end{array}$ \\
\hline Sharma (2019) & $\begin{array}{l}\text { What are Saudi students' } \\
\text { attitudes toward using } \\
\text { social media to support } \\
\text { their EFL learning, } \\
\text { mainly at Jazan }\end{array}$ & $\begin{array}{l}\text { Students had a } \\
\text { positive attitude } \\
\text { toward using Social } \\
\text { Media (SM)to } \\
\text { Support their EFL }\end{array}$ & $\begin{array}{l}\text { Students were } \\
\text { concerned about their } \\
\text { privacy when using } \\
\text { SM. }\end{array}$ \\
& University? & $\begin{array}{l}\text { surners } \\
\text { learning. They } \\
\text { preferred WhatsApp } \\
\text { then YouTube. }\end{array}$ & \\
& & &
\end{tabular}

Social Media

Alshehri, Rutter \& How do you rate the Smith (2019)
How do you rate the
usability features of
Students had positive None views of Blackboard 
Khaled Layali \& Ahmed Al-Shlowiy

Students' perceptions of e-learning for ESL/EFL in Saudi universities at time of coronavirus: A literature review

250 Students

King Khaled Uni.

2 questionnaires

(usability \& perceptions)

Blackboard

Oyaid \& Alshaya (2019)

27 students

A Saudi uni.

Discussion group

E-book app.

Mutambik (2018)

16 students \& 8 teachers

Saudi public schools

Group interviews

E-learning
Blackboard? What are your perceptions of these features? (implied)

How was your experience using Ebooks? Did you face any difficulty while using it? (implied)

What are students' and teachers' perceptions of using e-learning for EFL learning in Saudi schools? (implied) perceived its most

important usability

features were:

information quality, navigation and

learnability

respectively.

Students had positive views of E-book app and thought its most important features were: interactivity, user-friendly interface and the ability to highlight important parts of the E-book text.

Students had positive views of e-learning and used it particularly for listening and speaking. They report many benefits of elearning such as: independent, flexible and interactive learning.
Some students reported they couldn't copy part of the text in the E-book app and paste it into other apps. Some reported not being used to study from a screen.

Some students were concerned about not developing handwriting properly when used to elearning.

The present review had three objectives. First, it aimed to report on the students' perceptions of the various e-learning technologies such as LMSs such as WebCT, Blackboard and Moodle; Mobile applications such as Telegram and WhatsApp, video-conferencing tools such as Skype and Zoom; and Social Media sites such as Facebook, Blogs, Wikis and Google Docs for learning ESL/EFL in Saudi universities at Coronavirus time.

Second, it sought to find out the benefits of using such e-learning tools, platforms and applications for ESL/EFL in Saudi universities. For instance, in the historical perspective of the review's focus, Sharma (2019) stated that students at Jazan University preferred to use WhatsApp and YouTube for their EFL learning as social media was a panacea for their affective filters (i.e., increased their motivations and lowered their anxiety). Moreover, they could access their learning materials via these social media platforms and applications anytime anywhere.

Third, it endeavored to report any drawbacks for using these e-learning tools, platforms and applications for ESL/EFL learning in Saudi universities and offer solutions. Foe example, in the historical perspective of the review's focus, Oyaid and Alshaya (2019) stated that students in one Saudi university had positive views of using an E-book application however, some students reported they could not copy some parts of the E-book text and paste it in other applications. Furthermore, some students stated they were not used to studying from a screen.

Based on the four previously mentioned studies in the historical perspective of the review section, the students' perceptions were expected to be mainly positive ones. E-learning tools, platforms and applications were expected to bear many benefits for ESL/EFL learning in Saudi universities. However, if any drawbacks existed as per the students, these would be reported along with suggested solutions as well.

\section{METHOD}


This review covered the period from January 2020 till April 2020 as it attempted to capture the students' perceptions of e-learning for ESL/EFL in Saudi universities at Coronavirus time. Two preliminary search engines were used: Google Scholar and Education Resources Information Center (ERIC). The main keywords used in the search were: students' perceptions, e-learning for ESL/EFL, Saudi universities and Coronavirus time. When the researchers included Coronavirus in the keywords used for the search, Google Scholar turned zero hits and ERIC turned seven hits retrieved on April 15, 2020. When removing Coronavirus from the keywords used for the search, Google Scholar turned 13 hits and ERIC turned 28 hits retrieved on April 15, 2020. The researchers noticed that the seven hits found by ERIC when using the keyword Coronavirus time are included in the 28 hits found by ERIC when removing this keyword from the search. So, the researchers decided to peruse all the 28 found hits by ERIC and the 13 hits by Google Scholar as well.

Criteria for choosing the review studies

Certain criteria were used in deciding on which studies to be reviewed out of the found hits by ERIC and Google Scholar. These were:

- Primary studies only; not reviews, nor position papers.

- Studies from January 2020 till April 2020 (the time for Coronavirus pandemic's world outbreak in many countries including Saudi Arabia).

- Studies focusing on students' perceptions; not the teachers' nor administrators'/policy makers' perceptions.

- Studies in Saudi universities in Saudi Arabia.

Rationale for choosing the criteria

Primary studies give us first-hand experience of the research as they are conducted and reported by the researchers who performed such studies themselves (Perry, 2011) that is why these studies were chosen. The period from January to April 2020 was chosen as it is the time of Coronavirus outbreak in many countries in the world including Saudi Arabia. On January 30, 2020, WHO declared COVID-19 as a world pandemic. Moreover, studies focusing on students' perceptions were used as the researchers subscribe to the benefits of student-centered education such as students' share responsibility of their learning with their teachers, students interact with the teachers and students collaborate and communicate with each other (Oinam, 2017). Finally, Saudi universities were focused on rather than schools as the language of instruction in Saudi Universities for scientific majors is English and the humanities majors have to study an English course as a graduation requirement (Alrashidi \& Phan, 2015).

\section{Excluded studies and reasons}

One study (Alshammari, 2020) was excluded as it tackled Chinese rather than English in Saudi Arabia. A second study (Abed \& Shackleford, 2020) was excluded as it focused on learning disabled students and how to support them. A third study (Alzahrani \& Althaqafi, 2020) was excluded as it focused on teachers' perceptions of online professional development. A fourth study (Alyami, 2020) was excluded as it focused on e-learning integration from the perception of concerned bodies: administrators and policy makers.

Four relevant studies

Thus, four studies were found relevant to the review. The first study (Ahmed, 2020) reported on an elearning tool (Google Docs), students' reflections on its use and how its use led to improving the quality of the students' EFL writing in Imam Abdulrahman University. The second study (Abu-Ayfah, 2020) reported on another e-learning tool (Telegram app.) for EFL learning and the students' views of it in Taibah University. The third study (Alshehri and Cumming, 2020) reported on a third e-learning tool (Mobile technologies) and the students' and teachers' perceptions of these in King Abdulaziz and King Khalid universities. The fourth study (Hakami, 2020) reported on a fourth e-learning tool (Nearpod) and the students' perspectives of it in Najran University.

\section{RESULTS AND DISCUSSION}

Ahmad (2020) sought to answer the research question: What is the effect of Cloud-based Collaborative Writing (CBCW) on both the quantity and quality of EFL students' writing? There were two hypotheses: 1) a statistically significant difference would be found between the mean scores of participants between the pretest and the posttest of writing quantity, and 2) a statistically significant 
difference would be found between the mean scores of participants between the pretest and the posttest of writing quality.

The participants were 21 female students at Jubail College of Education, Imam Abdulrahman University (IAU). They were EFL students with the Dept of English enrolled in a course called Advanced Essay. They were familiar with using computers, smart phones and Blackboard in their studies. Pre- and post- essay writing tests were used to measure the students' quantity and quality of their writing. The treatment was using Google Docs to write weekly essays. Students were divided in small groups and each group collaborated in writing their own essay. Google Docs was chosen as it was a free online cloud-based collaboration tool with simple interface. Moreover, it could support synchronous and asynchronous communication and revision by various writers from various locations on one or more documents.

Two training sessions were administered to the participants to make sure they could do the weekly writing task via Google Docs properly. After completing their collaborative Google Docs essay writing over one semester, the participants were also required to reflect on their collaborative writing experiences as well as their experiences using Google Docs. Their reflections and comments were written on Google Docs discussion page.

Results showed that the difference between the mean scores of the participants' pretest and posttest of writing quantity was not significant whereas it was significant for the writing quality. This was done using Wilcoxon Signed Ranks test. The researcher concluded that Cloud-based Collaborative Writing (CBCW) could be used to improve the quality of essays written by EFL students. Most students had favorable views of using Google Docs for collaborative writing.

Moreover, Abu-Ayfah (2020) attempted to answer the research question: What are the EFL college students' perceptions of using Telegram Application for English language learning? The participants were 300 randomly selected EFL college students, 200 female and 100 male, from the department of English and Translation at Taibah University. The majority of participants were familiar with the Telegram app. and already used it for learning EFL. Telegram is a cloud-based app. that could allow exchanging text, pictures, audio or video among its users without occupying storage space on their mobile/smart phones.

The instrument was a questionnaire administered via Google online survey and distributed via a WhatsApp group. The first section of the questionnaire asked about the participants' gender and use of Telegram Application. The second section included 24 statements related to the research question. The study was quantitative and used the descriptive, analytical method and the statistical software SPSS.

Results showed that 35\% of the participants used Telegram app. for both language skills betterment and entertainment. Also, 29\% used it for language improvement alone, $26 \%$ used it for other purposes, and $10 \%$ used it for fun alone. Moreover, $66 \%$ of the participants used Telegram app. for EFL vocabulary learning and 64\% used it for EFL reading. About $63 \%$ used it for grammar learning, 58\% used it for listening, 57\% used it for speaking, and 57\% used it for writing. The researcher concluded that students used Telegram app. for EFL learning and most of them favored to learn vocabulary via it than other language skills.

Alshehri and Cumming (2020) sought to answer the research question: How does the integration of mobile technologies affect knowledge management among students and educators in academic (higher education) settings? Three sub-questions were asked:

1) What are students' perspectives of using mobile applications for knowledge management (including formal and informal communication) in academic settings?

2) What are lecturers' perspectives of using mobile applications for knowledge management (including formal and informal communication) in academic settings?

3) How do mobile technologies address the shortcomings of the current learning system for knowledge management?

Participants were 30 students and 31 educators from Linguistics, Math, and Information and Communication Technology (ICT) departments at King Abdulaziz University and King Khalid University. Qualitative data were gleaned via semi-structured interviews that aimed to obtain the participants' perceptions of mobile technologies for learning and academic purposes. The interviews were audio recorded, transcribed, and then translated from Arabic to English.

Results showed that mobile technologies enabled students to access learning materials anytime anywhere, solve problems via communication with other students and their teachers. One student 
explained when he faced a difficult part while studying; he used mobile applications to contact his fellow students and his teacher for clarification.

Moreover, students and teachers posited that using mobile technologies enhanced academic communication, such as asking questions and seeking clarification of difficult points. However, some students conceived some drawbacks for integrating mobile technologies, such as slow Internet connectivity and asked for institutional support to solve such a problem.

The researcher concluded that students and teachers believed that mobile technologies enhanced academic, student-student and student-teacher communication. Institutional support and training for both students and teachers are needed for best outcomes.

Hakami (2020) contrived to answer the research question: Do Nearpod affordances promote female students' interaction in a Bring Your Own Device (BYOD) learning environment? Participants were 74 female students enrolled in a School Administration course at Sharoura College of Science and Arts, Najran University.

Nearpod is a web-based learning application that facilitates interaction among students and between students and their teachers. Students can use the application on their own devices such as tablets, smart phones or laptops. Nearpod was integrated to a video-conferencing system that allowed male teachers to teach female students at Najran University. In Saudi Arabia, there are separate campuses for male and female students. Male teachers can teach female students only via a videoconferencing system due to religious and cultural practices in the country.

The instrument was a questionnaire to obtain students' perceptions of Nearpod integrated with a video-conference system in a BYOD learning model. A 5-point Likert scale, ranging from 'strongly disagree' to 'strongly agree' was used to rate the students' views in Oyaid and Alshaya (2019). Moreover, 5 open-ended questions were also included in the questionnaire to gain more in-depth information. Data was analyzed using descriptive statistical analysis. Verbal responses for the openended questions were perused and categorized into codes and themes.

Results showed that $90 \%$ of the students agreed that integrating Nearpod with the videoconferencing system led to more interaction in class. About $87 \%$ of the students believed that Nearpod enhanced collaborative activities among students leading to better understanding of lectures. However, some participants reported some disadvantages for using Nearpod mainly the slow Internet connectivity that affects the quality of Nearpod. Also, some students did not like using their own devices in class in the BYOD learning model.

The researcher concluded that most students had positive views of integrating Nearpod with a video-conferencing system in a BYOD learning environment as this promoted more interaction, collaboration among students and enhanced communication with the teacher leading to better understanding of the learning materials.

\section{Summary of major results}

The four reviewed primary studies (Abu-Ayfah, 2020; Ahmad, 2020; Alshehri \& Cumming, 2020 and Hakami, 2020) clearly indicated that students had positive views of the various e-learning applications for ESL/EFL in Saudi universities. For instance, Abu-Ayfah (2020) stated that male and female students in the Dept. of English and Translation, Taibah University, had positive perspectives of Telegram (i.e., a cloud-based app. for exchanging text, pictures, audio and video) for EFL learning. Students favored this app. for learning vocabulary more than reading, grammar, listening, speaking and writing respectively. Ahmad (2020) reported that female students at the English Dept. of Jubail College of Education, Imam Abdulrahman University (IAU) had favorable perceptions of using Google Docs (i.e., a free cloud-based online collaborative writing tool) for EFL writing. Moreover, using Google Docs was found to improve the students' writing quality.

Alshehri and Cumming (2020) posited that students and teachers in the Dept. of Linguistics, Math and ICT of King Abdulaziz University and King Khalid University had positive perceptions of integrating mobile technologies at these universities. Students and teachers believed integrating mobile technologies enhanced academic, student-student and student-teacher communications. However, a minor drawback was reported by some students, namely slow Internet connectivity. Institutional support was reported important to solve this minor problem.

Hakami (2020) reported that female students at Sharoura College of Science and Arts of Najran University had favorable views of Nearpod (i.e., a web-based learning app.) when integrated with a 
video-conferencing system in a Bring Your Own Device (BYOD) learning environment. Students posited that Nearpod promoted more interaction, collaboration among students, and communication with the teacher. However, slow Internet connectivity was reported by some students as a little disadvantage. In addition, some students did not like bringing their own devices in a BYOD model. For an outline of the review's four studies, please refer to Table 2.

Table 2. Outline of the review's four studies

\begin{tabular}{|c|c|c|c|}
\hline $\begin{array}{l}\text { Study/participants/ } \\
\text { setting/instrument/platform }\end{array}$ & Research question(s) & $\begin{array}{l}\text { Results } \\
\text { (benefits) }\end{array}$ & $\begin{array}{l}\begin{array}{l}\text { Results } \\
\text { (drawbacks) }\end{array} \\
\end{array}$ \\
\hline $\begin{array}{l}\text { Ahmad (2020) } \\
21 \text { female students } \\
\text { College of Education, Jubail. } \\
\text { Pre- and post- essay writing } \\
\text { tests } \\
\text { Google Docs }\end{array}$ & $\begin{array}{l}\text { What is the effect of } \\
\text { Cloud-based } \\
\text { Collaborative Writing } \\
\text { (CBCW) on both the } \\
\text { quantity and quality of } \\
\text { EFL students' writing? }\end{array}$ & $\begin{array}{l}\text { Most students had } \\
\text { favorable views of } \\
\text { Google Docs for } \\
\text { collaborative writing; } \\
\text { using Google Docs } \\
\text { improved writing } \\
\text { quality. }\end{array}$ & None. \\
\hline $\begin{array}{l}\text { Abu-Ayfah (2020) } \\
200 \text { female \& } 100 \text { male } \\
\text { students, English Dep. At } \\
\text { Taiba Uni. } \\
\text { Questionnaire } \\
\text { Telegram app. }\end{array}$ & $\begin{array}{l}\text { What are the EFL } \\
\text { college students' } \\
\text { perceptions of using } \\
\text { Telegram app for } \\
\text { English language } \\
\text { learning? }\end{array}$ & $\begin{array}{l}\text { Students used } \\
\text { Telegram for EFL } \\
\text { learning and most of } \\
\text { them favored to learn } \\
\text { vocabulary via it than } \\
\text { other language skills. }\end{array}$ & None. \\
\hline $\begin{array}{l}\text { Alshehri \&Cumming (2020) } \\
30 \text { students \& } 31 \text { educators } \\
3 \text { departments at KAAU \& } \\
\text { KKU. Semi-structured } \\
\text { interviews } \\
\text { Mobile technologies }\end{array}$ & $\begin{array}{l}\text { How does the } \\
\text { integration of mobile } \\
\text { technologies affect } \\
\text { knowledge } \\
\text { management among } \\
\text { students and educators } \\
\text { in academic (higher } \\
\text { education) settings? }\end{array}$ & $\begin{array}{l}\text { Students and teachers } \\
\text { believed that mobile } \\
\text { technologies } \\
\text { enhanced academic } \\
\text { and student- } \\
\text { student/student- } \\
\text { teacher } \\
\text { communication. }\end{array}$ & $\begin{array}{l}\text { Slow Internet } \\
\text { connectivity. }\end{array}$ \\
\hline $\begin{array}{l}\text { Hakami (2020) } \\
74 \text { female students } \\
\text { Sharoura College of S \& A, } \\
\text { Najran Uni. } \\
\text { Questionnaire \& open-ended } \\
\text { questions } \\
\text { Nearpod }\end{array}$ & $\begin{array}{l}\text { Do Nearpod } \\
\text { affordances promote } \\
\text { female students' } \\
\text { interaction in a Bring } \\
\text { Your Own Device } \\
\text { (BYOD) learning } \\
\text { environment? }\end{array}$ & $\begin{array}{l}\text { Students had positive } \\
\text { views of Nearpod as } \\
\text { it promoted more } \\
\text { interaction, } \\
\text { collaboration among } \\
\text { students and } \\
\text { enhanced } \\
\text { communication with } \\
\text { the teacher. }\end{array}$ & $\begin{array}{l}\text { Slow Internet } \\
\text { connectivity that } \\
\text { affected the } \\
\text { quality } \\
\text { Nearpod. Some } \\
\text { students did not } \\
\text { like using their } \\
\text { own devices in a } \\
\text { BYOD learning } \\
\text { environment. }\end{array}$ \\
\hline
\end{tabular}

Thus, the review's four studies re-affirmed what was reported by the historical perspective's other four studies (Alshehri, Rutter \& Smith, 2019; Mutambik, 2018; Oyaid \& Alshaya, 2019; Sharma, 2019;). Students' perspectives of e-learning for ESL/EFL learning in Saudi universities were positive attesting to its many benefits with some minor drawbacks. For an outline of the eight studies' elearning benefits and drawbacks, it is summarized in Table 3.

Table 3. Outline of the eight studies' e-learning benefits/drawbacks

\begin{tabular}{llll}
\hline Study & e-learning tool & Benefits & Drawbacks \\
\hline $\begin{array}{l}\text { Sharma } \\
(2019)\end{array}$ & $\begin{array}{l}\text { Social Media } \\
\text { (SM) }\end{array}$ & $\begin{array}{l}\text { Students had a positive attitude toward } \\
\text { using Social Media (SM)to support their } \\
\text { EFL learning. They preferred WhatsApp } \\
\text { then YouTube. }\end{array}$ & $\begin{array}{l}\text { Students were concerned } \\
\text { about their privacy when } \\
\text { using SM. }\end{array}$ \\
$\begin{array}{l}\text { Alshehri, } \\
\begin{array}{l}\text { Rutter and } \\
\text { Smith (2019) }\end{array}\end{array}$ & Blackboard & $\begin{array}{l}\text { Stacks had positive views of } \\
\text { Blackoard perceived its most important } \\
\text { usability features were: information }\end{array}$ & None \\
\hline
\end{tabular}




\begin{tabular}{|c|c|c|c|}
\hline & & $\begin{array}{l}\text { quality, navigation and learnability } \\
\text { respectively. }\end{array}$ & \\
\hline $\begin{array}{l}\text { Oyaid \& } \\
\text { Alshaya } \\
(2019)\end{array}$ & E-book app. & $\begin{array}{l}\text { Students had positive views of E-book } \\
\text { app and thought its most important } \\
\text { features were: interactivity, user-friendly } \\
\text { interface and the ability to highlight } \\
\text { important parts of the E-book text. }\end{array}$ & $\begin{array}{l}\text { Some students reported } \\
\text { they couldn't copy parts of } \\
\text { the text in the E-book app } \\
\text { and paste it into other apps. } \\
\text { Some reported not being } \\
\text { used to study from a } \\
\text { screen. }\end{array}$ \\
\hline $\begin{array}{l}\text { Mutambik } \\
(2018)\end{array}$ & $\begin{array}{l}\text { E-learning tools } \\
\text { in general. }\end{array}$ & $\begin{array}{l}\text { Students had positive views of e-learning } \\
\text { and used it particularly for listening and } \\
\text { speaking. They reported many benefits of } \\
\text { e-learning such as: independent, flexible } \\
\text { and interactive learning. }\end{array}$ & $\begin{array}{l}\text { Some students were } \\
\text { concerned about not } \\
\text { developing handwriting } \\
\text { properly when used to e- } \\
\text { learning. }\end{array}$ \\
\hline $\begin{array}{l}\text { Ahmad } \\
(2020)\end{array}$ & Google Docs. & $\begin{array}{l}\text { Most students had favorable views of } \\
\text { Google Docs for collaborative writing; } \\
\text { using Google Docs improved writing } \\
\text { quality. }\end{array}$ & None \\
\hline $\begin{array}{l}\text { Abu-Ayfah } \\
(2020)\end{array}$ & Telegram app. & $\begin{array}{l}\text { Students used Telegram for EFL learning } \\
\text { and most of them favored to learn } \\
\text { vocabulary via it than other language } \\
\text { skills. }\end{array}$ & None \\
\hline $\begin{array}{l}\text { Alshehri \& } \\
\text { Cumming } \\
(2020)\end{array}$ & $\begin{array}{l}\text { Mobile } \\
\text { technologies. }\end{array}$ & $\begin{array}{l}\text { Students and teachers believed that } \\
\text { mobile technologies enhanced academic } \\
\text { and student-student/student-teacher } \\
\text { communication. }\end{array}$ & Slow Internet connectivity. \\
\hline $\begin{array}{l}\text { Hakami } \\
(2020)\end{array}$ & $\begin{array}{l}\text { Nearpod, a } \\
\text { web-based } \\
\text { learning app. }\end{array}$ & $\begin{array}{l}\text { Students had positive views of Nearpod } \\
\text { as it promoted more interaction, } \\
\text { collaboration among students and } \\
\text { enhanced communication with the } \\
\text { teacher. }\end{array}$ & $\begin{array}{l}\text { Slow Internet connectivity } \\
\text { that affected the quality of } \\
\text { Nearpod. Some students } \\
\text { did not like using their own } \\
\text { devices in a BYOD } \\
\text { learning environment. }\end{array}$ \\
\hline
\end{tabular}

\section{Drawbacks and solutions}

The drawbacks reported were slow Internet connectivity (Alshehri and Cumming, 2020); not preferable to bring own device in a BYOD environment (Hakami, 2020); privacy of students on Social Media (SM) (Sharma, 2019); not being used to study from a screen and not being able to copy from Ebook text and paste into other applications (Oyaid \& Alshaya, 2019); and worry about handwriting development when used to e-learning (Mutambik, 2018). Such minor drawbacks can easily be fixed via institutional support from universities to enhance the Internet connectivity and via e-learning software designers to promote students' privacy on SM and to add more available options, such as the possibility to copy from an E-book text and paste into other apps. Finally, as for not being used to study from a screen or worry about own handwriting, spending more time doing these activities warrants improvement in such respects.

\section{Web 0.2 and learning theories}

The students' mainly positive views of e-learning can be attributed to the features of web 0.2 , which support and facilitate these e-learning applications. Web 0.2 has interactive interface enabling twoway student-student and student-teacher communication. Such a feature allows for social learning where students help each other and receive a help from their teachers via feedback (Hartshorne \& Ajjan, 2009).

Furthermore, the built-in affordances in these e-learning applications, such as Google Docs, allow synchronous and asynchronous communication and revision by various writers from various locations on one or more documents. Moreover, Telegram app. allows for the exchange of text, pictures, audio and video among students and between students and teachers.

Such e-learning affordances can support student-student and student-teacher interaction, communication, and collaboration while writing some essays together or exchanging texts/pictures or 
audios/videos of some ESL/EFL topics leading to better understanding of the learning materials and language skills.

This concurs with Vygotsky's (1978) Socio-cultural Theory of learning where

interaction between novice-master, peer-peer, and student-student leads to master scaffolding novice-teacher scaffolding student-student scaffolding student with the result that the novice learns the skill/ the student learns the language skill better.

Also, SM as an e-learning tool; such as Facebook, WhatsApp, wikis, blogs, etc.; can motivate students, lower their anxiety, and allow them to work together on various language skills such as listening, speaking, reading, and writing while being in a low-threatening atmosphere.

This is in line with Krashen's (1981) affective filter hypothesis where low anxiety and high motivation allows the language input to pass through the learners' affective filter and reach the Language Acquisition Device (LAD). Thus, students learn the language skill at hand.

\section{A conference paper from China}

In a reaction to the new COVID-19 and the suspension of face-to-face education, He (2020) presented a conference paper at a conference held in the beginning of March 2020 in China. In his paper, he proposed a specific solution for College English learners in China, which he called 'online autonomous learning.'

$\mathrm{He}$ (2020) posited that in foreign language learning/teaching (such as College English learning/teaching), the absolute autonomy of learning is not realistic. Learners' autonomy or studentcentered learning should be under the teachers' guidance where the teacher becomes a mentor or a consultant (Littlewood, 1999).

$\mathrm{He}$ (2020) further explained that in an online environment, autonomous learners use the help of their teachers (Gardner \& Miller, 1999). Online College English teachers and learners build an online learning community via interaction between learners and teachers and among learners. The learning tasks are completed via student-student as well as student-teacher collaboration and interaction. Teachers need to provide students with online rich learning resources and guide students on how to evaluate other Internet resources for learning to avoid poor online learning materials.

\section{CONCLUSION}

In China, he (2020) called for continuing College English learning during Coronavirus shut down period via online autonomous learning where both learners and teachers build an online interactive learning community. Likewise, in Saudi Arabia, since students' perceptions were in favor of elearning for ESL/EFL in Saudi universities, the researchers call for its adoption as the only viable means of learning, with documented benefits and marginal drawbacks, that is favored by students at such world pandemic's time.

\section{REFERENCES}

Abed, M. G., \& Shackelford, T. K. (2020). Educational support for Saudi students with learning disabilities in higher education. Learning Disabilities Research \& Practice, 35(1), 36-44.

Abu-Ayfah, Z. A. (2020). Telegram app in learning English: EFL students' perceptions. English Language Teaching, 13(1), 51-62.

Ahmad, S. Z. (2020). Cloud-based collaborative writing to develop EFL students' writing quantity and quality. International Education Studies, 13(3), 51-64.

Aifan, H A. (2015). Saudi Students' attitudes toward using social media to support learning (unpublished doctoral thesis). University of Kansas, USA.

Alarabiya Net. (2020). Saudi today. Retrieved on April 15, 2020, from https://www.alarabiya.net/ar/sauditoday/2020/03/15.

Alrashidi, O., \& Phan, H. (2015). Education context and English teaching and learning in the Kingdom of Saudi Arabia: An overview. English Language Teaching, 8(5), 33-44.

Alshammari, H. (2020). Chinese Language in Saudi Arabia: Challenges and Recommendations. English Language Teaching, 13(2), 75-85.

Alshehri, A., \& Cumming, T. M. (2020). Mobile technologies and knowledge management in higher education institutions: Students' and educators' perspectives. World Journal of Education, 10(1), 12-22. 
Alshehri, A., Rutter, M., \& Smith, S. (2019). Assessing the relative importance of an e- learning system's usability design characteristics based on students' preferences. European Journal of Educational Research, 8(3), 839-855.

Alyami, H. Y. (2020). Integration of open educational resources in higher and general education institutions: From the perspectives of specialized and concerned bodies in e-learning. World Journal of Education, 10(1), 30-41.

Alzahrani, F. Y., \& Althaqafi, A. S. (2020). EFL Teachers' perceptions of the effectiveness of online professional development in higher education in Saudi Arabia. Higher Education Studies, 10(1), 121-131.

Arab News Website (2020). Saudi Arabia announces first case of coronavirus. Retrieved on April 8, 2020, from https://www.arabnews.com/node/1635781/saudiarabia.

Ellis, R. A., Ginns, P., \& Piggott, L. (2009). E-learning in higher education: Some key aspects and their relationship to approaches to study. Higher Education Research \& 303. Retrieved on May 1, 2020 from http://www.informaworld.com/10.1080/07294360902839909.

Gardner, D., \& Miller, L. (1999). Establishing self-access from theory to practice. Cambridge: Cambridge University Press.

Hakami, M. (2020). Using Nearpod as a Tool to Promote Active Learning in Higher Education in a BYOD Learning Environment. Journal of Education and Learning, 9(1), 119-126.

Hartshorne, R., \& Ajjan, H. (2009). Examining student decisions to adopt Web 2.0 technologies: theory and empirical tests. Journal of Computing in Higher Education, $\quad$ 21(3), 183-198.

He, B. (2020, April). Research on the autonomous learning mode of college English via the internet in the epidemic situation. Paper presented at the 5th International Conference on Social Sciences and Economic Development (ICSSED 2020) (127-130).

Kitchakarn, O. (2012). Using blogs to improve students' summary writing abilities. Turkish Online Journal of Distance Education, 13(4), 209-219.

Krashen, S. D. (1981). Second language acquisition and second language learning. Oxford: Pergamon Press.

Li, F. W., Lau, R. W., \& Dharmendran, P. (2009). A three-tier profiling framework for adaptive e-learning. Proceedings of the 8th International Conference on Advances inWeb Based Learning, Aachen.

Littlewood, W. (1999). Defining and developing autonomy in East Asian contexts. Applied linguistics, 20(1), 7194.

Mutambik, I. (2018). The Role of e-Learning in studying English as a foreign language in Saudi

Arabia: Students' and teachers' perspectives. English Language Teaching, 11(5), 74-83.

Nepomuceno, M. M. (2011). Writing online: Using blogs as an alternative writing activity intertiary ESL classes. TESOL journal, 5(2), 92-105.

Oinam, S. (2017). Student-centered approach to teaching and learning in higher education for quality enhancement. IOSR Journal of Humanities and Social Science, 22(6), 27-30.

Oyaid, A., \& Alshaya, H. (2019). Saudi University Students Views, Perceptions, and Future Intentions towards E-Books. Malaysian Online Journal of Educational Technology, 7(1), 69-75.

Perry, F. L. (2011). Research in applied linguistics: Becoming a discerning consumer. Oxford:: Taylor and Francis.

Saudi Gazette. (2020), Entry and prayer in courtyards of the Two Holy mosques suspended. Retrieved on April 15, 2020, from http://www.saudigazette.com.sa/article/591064.

Sharma, V. (2019). Saudi students' perspective on social media usage to promote EFL learning. International Journal of Linguistics, Literature and Translation, 2(1), 129-139.

Vygotsky, L. S. (1978). Mind in society: The development of higher psychological processes. Cambridge, MA: Harvard University Press.

World Health Organization. (2008). International health regulations (2005). World Health Organization. Retrieved on April 6, 2020, from https://www.who.int/ihr/about/en/.

World Health Organization. (2020). Coronavirus disease 2019 (COVID-19): Situation report\#1. Retrieved April 6, 2020, from https://www.who.int/docs/default source/coronaviruse/situation-reports/20200121-sitrep-12019 ncov.pdf?sfvrsn=20a99c10 4 .

World Health Organization. (2020). Coronavirus disease 2019 (COVID-19): Situation repor \#11. Retrieved April 8, 2020, from https://www.who.int/docs/default source/coronaviruse/situation-reports/20200131sitrep-11 ncov.pdf?sfvrsn=de7c0f7_4

Worldometer Website. (2020). Retrieved on April 7, 2020, from https://www.worldometers.info/coronavirus/country/saudi-arabia/. 
Khaled Layali \& Ahmed Al-Shlowiy

Students' perceptions of e-learning for ESL/EFL in Saudi universities at time of coronavirus: A literature review 